Session 3230

\title{
ASEE Student Chapters: From Student Members to Faculty
}

\author{
Jennifer Kadlowec ${ }^{1}$, Kurt DeGoede ${ }^{2}$, Trevor Harding ${ }^{3}$, Chris Lorenz ${ }^{4}$ \\ ${ }^{1}$ Rowan University, Glassboro, NJ / ${ }^{2}$ Elizabethtown College, Elizabethtown, \\ PA/ \\ ${ }^{3}$ Kettering University, Flint, MI / ${ }^{4}$ University of Michigan, Ann Arbor, MI
}

\begin{abstract}
The University of Michigan Student Chapter of the American Society for Engineering Education has grown from a small core group of founding members, who organized panel discussions for the graduate student community, into a flourishing student organization, which continues to grow in membership and events. The purpose of this paper is to promote graduate student chapters of the ASEE and demonstrate the positive impact that student member participation has had, particularly for those who have recently entered academia. Many events and activities of the University of Michigan Student Chapter of the American Society for Engineering Education (UM-ASEE Student Chapter) will be highlighted. The events range from brown bag lunches, panel discussions and student instructor awards to distinguished lectures, workshops and participation in the ASEE Annual Conferences. The benefits of the events along with the leadership and networking opportunities for students are discussed from the perspective of current student members and recent graduates, who are now college faculty. The chapter events and opportunities are provided as suggestions that other ASEE Student Chapters or similar student organizations may benefit from as well.
\end{abstract}

\section{Introduction}

The ASEE Student Chapter at the University of Michigan began in 1994 as a student-based organization committed to furthering education in engineering and engineering technology. This was to be accomplished by providing services to prepare members for a career in academia, educating undergraduate students about graduate education and encouraging involvement of underrepresented minority groups in academia and graduate school.

In 1994, a core group of students and faculty advisor, Dr. Susan Montgomery, worked to establish the UM-ASEE Student Chapter. The process consisted of developing a framework and constitution, becoming a recognized student organization on campus and chapter of the American

"Proceedings of the 2001 American Society for Engineering Education Annual Conference \& Exposition Copyright $\odot$ 2001, American Society for Engineering Education" 
Society for Engineering Education, electing officers and planning events. With the constitution ratified in August 1994, the first events during the 1994-95 academic year included a few panel discussions on topics pertinent to graduate students exploring careers in academia, presentations to undergraduate students about graduate school and the first Outstanding Graduate Student Instructor Awards.

Now in its seventh year, the UM-ASEE Student Chapter has continued to grow in membership, events and exposure. The organization still focuses its efforts toward two main groups: graduate and undergraduate engineering students. The goals of the organization [1] are summarized in Table 1.

\begin{tabular}{|l|l|}
\hline Graduate Students & Undergraduate Students \\
\hline $\begin{array}{l}\text { to inform students about various aspects of a career in } \\
\text { academia }\end{array}$ & $\begin{array}{l}\text { to dispel common misconceptions and to inform } \\
\text { students about the options and potential benefits of } \\
\text { attending graduate school }\end{array}$ \\
\hline $\begin{array}{l}\text { to enhance the teaching and presentation skills of } \\
\text { prospective educators }\end{array}$ & $\begin{array}{l}\text { to assist students in their preparation for graduate } \\
\text { school entrance requirements }\end{array}$ \\
\hline to encourage students to consider careers in academia & $\begin{array}{l}\text { to educate students on the availability of financial } \\
\text { assistance }\end{array}$ \\
\hline to assist students in their search for academic positions & $\begin{array}{l}\text { to develop the skills needed to establish and lead a } \\
\text { research program }\end{array}$ \\
\hline $\begin{array}{l}\text { Additionally, for both groups considered, the purpose of the University of Michigan Student Chapter of the ASEE } \\
\text { will be to encourage underrepresented minority participation through focused recruitment efforts and by } \\
\text { addressing concerns unique to minorities }\end{array}$ \\
\hline
\end{tabular}

Table 1

First this paper will summarize some of the events that are held in accordance with the purpose of the UM-ASEE Student Chapter. The reader is also referred to several papers, which discuss starting a chapter ${ }^{2,3}$, lessons learned ${ }^{4}$ or specific activities to help prepare future educators $^{5,6,7,8}$. The ideas in this paper as well as those mentioned above may be useful to other student chapters in starting an organization or planning chapter events. Now that several members are currently faculty, the authors offer insight into the positive impact that the UM-ASEE student chapter has had on its members. To this end, comments by students regarding the impact and benefits that the events and experiences had on them as graduate students and as faculty in their teaching careers will be discussed.

\section{UM-ASEE Student Chapter Events}

The UM-ASEE Student Chapter provides a variety of avenues for meeting the purpose of the organization. Since its inception, the main events hosted by UM-ASEE Student Chapter are panel discussions and brown-bag lunches on topics related to academic careers. Topics that have fueled panel discussions that are pertinent to the graduate students are: finding an academic job, curriculum vitas, grant proposal writing, interviewing, starting a research program, the state of teaching at various types of universities and patents and intellectual property. The format for these discussions begins with 3 to 5 panel members speaking briefly about the topic, followed by 
an extended question and answer period of active discussion between panel members and the audience. Panelists were generally faculty administrators and staff at UM, however occasionally faculty from other local institutions were brought in. Including panels with outside participation greatly enhanced this series. Brown-bag lunches provide an informal setting for discussions about topics such as managing personal and professional life.

In order to help graduate students enhance teaching and presentation skills, various teaching workshops are held by the UM-ASEE Student Chapter. In the early years of the organization, these workshops were led by the Center for Research, Learning and Teaching at the University of Michigan. The forum for these workshops was an open session for general topics or more informal sessions as part of training programs for student instructors in their respective engineering departments. As the UM-ASEE Student Chapter grew and funding opportunities became more available, many teaching workshops were led by leading scholars in engineering education. Dr. James Stice, Dr. Richard Felder and Dr. Rebecca Brent, Dr. Dan Budny and Dr. Charles Yokomoto, Dr. Ron Miller and Dr. Barbara Olds are among the renowned scholars who have led workshops hosted at the University of Michigan. The Educational Research Methods Division of the ASEE assisted with partial funding to the Student Chapter for some of these workshops.

The most recent addition to the teaching programs and workshops is the Engineering Teaching Development (ETD) Project. In 1999, the UM-ASEE Student Chapter started this multicomponent program designed to improve the long-term teaching skills of graduate student instructors. The program consists of three parts: college-wide workshops conducted by nationally recognized engineering educators, departmental training and mentoring programs for graduate student instructors and a Teaching Fellows Program for graduate students to team teach a course with a faculty member. ${ }^{5}$

The UM-ASEE Student Chapter in conjunction with the College of Engineering has developed and organized an annual Outstanding Student Instructor Award in recognition of excellence in engineering education. The award not only acknowledges the outstanding contributions of the individuals selected for the award, but also coincides with the goal of promoting excellence in engineering education and attracts new members. ${ }^{6}$ Students in the course and the faculty member, who is involved with teaching the course, nominate the student instructors. A committee consisting of students and faculty chooses five winners and one to three honorable mention candidates among the nominations.

In order to provide undergraduate students with a better understanding of graduate education and to support the increased involvement of underrepresented minorities in higher education, the ASEE Student Chapter sponsors a popular workshop "Getting into Graduate School" for guidance on topics such as selecting the right school, scholarships and the Graduate Record Exam. Members of the chapter also conduct seminars for undergraduate organizations of professional societies, honor societies and societies catering to traditionally underrepresented minorities in engineering.

"Proceedings of the 2001 American Society for Engineering Education Annual Conference \& Exposition Copyright $@$ 2001, American Society for Engineering Education” 


\section{Lessons Learned}

The UM-ASEE Student Chapter has learned valuable lessons during seven years of experience. Other student chapters may benefit from the following, which list of sources of funding that help make the events mentioned possible (Table 2) and a Top 15 list of lessons learned (Table 3).

\section{Funding Sources}

Contact College of Engineering department chairs to support activities, which are directed toward professional development of graduate students. Many departments sponsor student organization activities and ASEE encompasses all engineering disciplines.

Request funds directly from the associate dean for undergraduate education to support activities that recognize outstanding graduate student instructors and activities that promote graduate school to undergraduate students.

Register with and request funds from Student Government Associations, which provide funds to organizations on campus for events.

If your school has a separate graduate school and/or graduate student government, request travel grants to support member travel to the ASEE National conference, or general funds for events and teaching workshops

Contact the ASEE-ERM Division for support of teaching enrichment workshops, which has help fund two of the workshops previous mentioned.

Table 2

\begin{tabular}{|l|l|}
\hline \multicolumn{2}{|l|}{ Top 15 Lessons Learned } \\
\hline 1 & Advertise! Advertise! Advertise! \\
\hline 2 & "Free food" attracts students \\
\hline 3 & Decide on a few specific events and do them well, then expand over the years as your organization sees fit \\
\hline 4 & Successful panel discussions address a specific concern \\
\hline 5 & $\begin{array}{l}\text { Teaching method workshops are best attended if the speaker is a well-known educator and/or administrative } \\
\text { support }\end{array}$ \\
\hline 6 & $\begin{array}{l}\text { Coordinate events with one or two highly placed champions at your institution (for example Dean of UG } \\
\text { education) to maximize the impact and attention on campus. }\end{array}$ \\
\hline 7 & Coordinate activities with other organization on campus that have common interests \\
\hline 8 & $\begin{array}{l}\text { Develop a list of benefits of the ASEE chapter and participation lists to help describe the importance of } \\
\text { events when speaking to department chairs and other funding sources }\end{array}$ \\
\hline 9 & Use sign in lists to establish mailing lists and participation lists for above \\
\hline 10 & Utilize ERM and ASEE resources \\
\hline 11 & Cash awards and a recognition event increase excitement for Teaching Awards \\
\hline 12 & $\begin{array}{l}\text { Remain active in ASEE at the national level. Attending conferences is a benefit for members for their hard } \\
\text { work and incentive for attracting new members. }\end{array}$ \\
\hline 13 & Encourage members to write ASEE, FIE or JEE papers. \\
\hline 14 & $\begin{array}{l}\text { Promote interest among new members to continue the positive influence of the organization on future } \\
\text { educators }\end{array}$ \\
\hline 15 & Consult other ASEE student chapters for ideas and suggestions \\
\hline
\end{tabular}

Table 3

"Proceedings of the 2001 American Society for Engineering Education Annual Conference \& Exposition Copyright @ 2001, American Society for Engineering Education” 


\section{Discussion of Student Chapter Benefits}

In order to determine the impact that the UM-ASEE chapter had on members of the organization and to provide feedback to the current student chapter, the authors surveyed current members and recent graduates, who are now university faculty members. Among the graduates surveyed are educators at both $\mathrm{PhD}$ and non-PhD granting universities, who graduated from the University of Michigan between 1997 and 2000. This section describes the benefits of the student chapter and events from the perspective of these members.

One important benefit for the members is that the student chapter provides a forum for students to meet and discuss academic or graduate school issues with one another. Students found the chapter to be an outlet to meet other graduate students, who shared an interest in pedagogical issues. Informal meetings gave students the opportunity to talk to peers about teaching techniques they tried in the classroom and the effectiveness of them. This was particularly beneficial for student instructors. Besides teaching issues, students entering the academic job market found their peers to be important contacts to discuss issues such as finding positions, interviewing and contract negotiations. Now that several University of Michigan alumni are university faculty members, having a contact base of these members provides for a valuable network. Finally, students found the student chapter to be a good avenue for social interaction outside of the daily graduate routine of classes and research.

Participation in regional and national conferences has benefited student chapter members in several ways. Beside contacts with faculty and students at the University of Michigan, those students who participated in the national conference made contacts with student chapter members and faculty at other universities. Meeting with other student chapter members provided the opportunity to share ideas regarding student chapter events, academic job searching and teaching methods. National conferences provided a place to meet faculty from a wide variety of universities, including those without $\mathrm{PhD}$ programs. This was of great value for several student members, including three of the authors, who were searching and found positions at these types of institutions, which focus on undergraduate education. Attending presentations at conferences gave the student members the chance to see techniques that other engineering educators are trying. Several members have written and presented their own papers at conferences as part of their commitment to engineering education.

Another significant benefit for the members was participation in the chapter events, such as panel discussions and teaching workshops. Topics for panel discussions included finding an academic job, curriculum vitas, proposal writing, interviewing, starting a research program, interdisciplinary research, teaching methods and state of teaching at research and non-research universities. All of the topics were rated favorably by those surveyed, with topics about finding an academic job and preparing a curriculum vita considered most informative. Current members and recent graduates found the teaching enrichment workshops to be highly productive. By bringing educators to campus gave students the opportunity to learn from nationally recognized engineering educators. Students commented that they have incorporated ideas they learned and employed techniques taught by these educators as graduate instructors and faculty members.

"Proceedings of the 2001 American Society for Engineering Education Annual Conference \& Exposition Copyright $@$ 2001, American Society for Engineering Education" 
Members, who served as officers in the student chapter, found the opportunity to improve their leadership skills and to work with many other students, faculty and administration. The principal leadership skills students developed were those required to organize successful College-wide events. Students worked together, delegated responsibilities and promoted participation in the organization of events. Working with the college administrators taught officers how to garner support and sell ideas and events, which satisfy the interests of the administration, faculty and the student-focused group. Current and past student chapter members found that the leadership roles have allowed them to acquire skills that will be useful to improve the educational climate at their respective institutions.

Alumni of the UM-ASEE Student Chapter have continued their association in ASEE to various extents as faculty. Most have remained ASEE members, enjoy reading PRISM and continue improving as educators. Several have written papers and participated in regional and division activities. Some members have become more active in ASEE by taking on duties such as serving on committees and as division officers, reviewing papers and chairing conference sessions. For these junior faculty, early involvement as a graduate student has accelerated the level of involvement for some of the members at the national level as junior faculty and allowed them to develop further contacts in academia.

Participating in the student chapter and teaching workshops, attending and presenting at conferences and receiving awards such as the Outstanding Student Instructor award have all reflected positively during the selection and interview process of student members who are now faculty and helped them in their current positions. All of these exhibit their interest and commitment to engineering education. Panel discussions and personal contacts provided useful discussions and information for finding academic positions. Teaching workshop and conferences are excellent sources for learning teaching methods and techniques that members utilized as student instructors and faculty members. New faculty have taken on responsibilities and leadership roles in the national ASEE organization and believe that early participation as graduate students has helped them in these new roles.

\section{Conclusion}

Since inception in 1994, the UM-ASEE Student Chapter is a continually growing student organization, which promotes engineering education. Along the way this chapter has learned several lessons (Table 2) and found a variety of funding sources (Table 3) that may be beneficial to those starting a new chapter or those in newer groups. A variety of events hosted by the UMASEE student chapter were discussed. Based on comments from both current students and recent graduates, the UM-ASEE Student Chapter members have greatly benefited from the events and their involvement in ASEE, both as students and as new faculty members. The authors encourage the growth and development of ASEE student chapters in order to continue serving undergraduate students in preparation for graduate studies and graduate students in preparation for positions in academia. Increased opportunities, such as ASEE student chapters, provide a forum for today's graduate students to promote change and improve engineering education as faculty tomorrow.

"Proceedings of the 2001 American Society for Engineering Education Annual Conference \& Exposition Copyright $\odot$ 2001, American Society for Engineering Education” 


\section{Acknowledgements}

The authors wish to thank Prof. Susan Montgomery and all of the current and past chapter officers for devotion to the UM-ASEE Student Chapter and making these important events possible. The authors thank Dean Wayne Jones for his advice and generous financial support of the chapter. Last, but not least, the authors thank the past and present student members that shared their comments for this paper.

Bibliography

1. University of Michigan Student Chapter of the American Society for Engineering Education Constitution, 1994. http://www.engin.umich.edu/soc/asee/constitution.html

2. Matsumoto, E., Arthur, L., Tumer, I., Gray, J., Serpas, F., Vogler, T., Jaramillo, N. and Barr, R. "How to Start an ASEE Student Chapter", Proceedings of the ASEE Conference 1998 - Session 2312.

3. Magill, M. "Building a Successful Student Chapter," Prism, December, 1996.

4. Mulkay, E., McComb, S., Kiesow, R., Boyd, D., Oakes, W. and Jones, J. "ASEE Student Chapters: Lessons Learned from the First Five Years", Proceedings of the ASEE Conference 1998 - Session 0555.

5. Soderstrom, S., Lorenz, C., Keinath, M. and Harding, T. "Implementing an Engineering Teaching Development Program for Graduate Student Instructors." Proceedings of the ASEE Annual Conference, 2000.

6. Kadlowec J., Shriver J., Harding T. and Choi, C. "Promoting Excellence in Education with an Outstanding Student Instructor Award Program." Proceedings of the ASEE Annual Conference, Session 0555, 1998.

7. Berger, E.J., Diefes, H.A., Hamaker, K.H., Jones, J.D., McComb, S.A., Mulkay, E.L. and Oakes, W.C. "ASEE Student Chapters: Perspectives on and Preparation for Higher Education", Journal of Engineering Education, July 1998, p.231-234.

8. Maynard, J., Garza, D., Finley, C., Tsurikov, M., Ulloa, F. and Barr, R. "Addressing Future Engineering Educators Through ASEE" Proceedings of the ASEE Conference 2000 - Session 0555.

JENNIFER KADLOWEC is an assistant professor in Mechanical Engineering at Rowan University. She received her BS in Physics from Baldwin-Wallace College and MSE and PhD degrees in Mechanical Engineering at the University of Michigan. While at the University of Michigan, she was actively involved with the UM-ASEE Student Chapter and developed computer-based modules for mechanical engineering.

KURT DEGOEDE is an assistant professor in Physics and Engineering at Elizabethtown College. He received his BSE at Hope College, MSE at Case Western Reserve University and PhD at the University of Michigan. While at the University of Michigan, he served as vice-president of the UM-ASEE Student Chapter.

"Proceedings of the 2001 American Society for Engineering Education Annual Conference \& Exposition Copyright @ 2001, American Society for Engineering Education" 
TREVOR HARDING is an assistant professor of Manufacturing Engineering at Kettering University. He received his $\mathrm{PhD}$ at the University of Michigan in Materials Science and Engineering, where he also received his BSE and MSE degrees. He was actively involved in the UM-ASEE Student Chapter, a graduate student mentor for the College of Engineering, and a member of the Graduate Student Advisory Panel to the Dean.

CHRIS LORENZ is a doctoral student in Chemical Engineering at the University of Michigan. He is currently serving as President of the ASEE Student Chapter. He received his BSE and MSE in Chemical Engineering from the University of Michigan concurrently in 1998. Chris was awarded the ASEE Outstanding Student Instructor Award for excellence in teaching in 1998 and a College-wide MLK Spirit Award in 1999.

"Proceedings of the 2001 American Society for Engineering Education Annual Conference \& Exposition Copyright (C) 2001, American Society for Engineering Education" 